\title{
Factors affecting productivity and the role of customer relationship management: A case study of home appliance manufacturing
}

\author{
Saeed Mirzamohammadi and Forough Basirat Fard*
}

Department of Industrial Engineering, Digital Unit, Iran University of Science \& Technology, Tehran, Iran

\begin{tabular}{l}
\hline A R T I C L E I N F O \\
\hline Article history: \\
Received July 18, 2011 \\
Received in Revised form \\
September, 12, 2011 \\
Accepted 1 October 2011 \\
Available online \\
6 October 2011 \\
\hline Keywords: \\
Productivity \\
Customer relationship \\
Management \\
EFQM \\
BSC
\end{tabular}

A B S T R A C T

In today's competitive world, productivity- as a core source of production - is the most important target of the organization. Experimental studies in developed industrial countries prove that productivity improvements resulted from development of management systems play a more important role in production than physical increases in labor and capital factors. This paper, while focusing on productivity from a CRM perspective, employs a European Organizational Excellence Model framework to identify factors affecting productivity and the role of CRM systems. We perform an empirical study for a case study of home appliance manufacturing and using a questionnaire computed present status and compared with desired status of CRM components such as customer leadership, strategy, skill and motivation of labor work, effective use of information technology and process management.

(C) 2012 Growing Science Ltd. All rights reserved.

\section{Introduction}

In view of the fact that efficient implementation of customer relations management imposes heavy expenses on the organizations, assuring their efficacy in improving productivity of organization and return of investment is a major concern for the senior managers of manufacturing industries. In the research carried out by far, the advantages of customer relations management have been studied from different aspects such as enhancing satisfaction, enhancing loyalty and so on, but its influence on productivity has not been specified systematically. In this paper, first definitions of productivity will be presented. Then the factors that influence productivity in the manufacturing organizations will be studied. Then we will specify which of these factors are under the influence of customer relations management. In order to show such influence European Organizational excellence Model has been used. Also customer-orientation success indices that influence productivity have been identified from four perspectives of balanced credit cards. And finally using the statistical analysis methods, we will assess the factors that influence productivity in manufacturing organizations and the role of customer relations management in it.

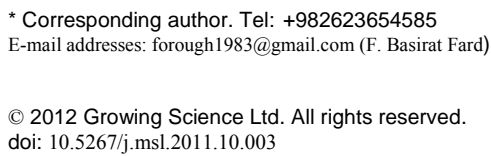




\subsection{Productivity}

The word productivity was for the first time used by mathematician and economist Francois Quesnay advocate of Physicroatia School.. By introducing table of economics, Quesnay believes that the power of every government depends on increasing productivity in agriculture section (Tangen, 2002). Productivity is the basis of performance or power and balance of every organization in production of goods and services. It is one of the most important effective factors of economic-manufacturing activities (Prokopenko,1996). Another definition of productivity is the creation of the value for customer (Brynjolfsson \& Hitt, 1998). In Table 1, definitions of productivity are specified from the viewpoints of national and international organizations.

\section{Table 1}

Productivity viewpoints of national and international organizations

\begin{tabular}{lll}
\hline productivity viewpoints & National and International Organizations & sources \\
\hline $\begin{array}{l}\text { Quotient of return to one of production factors } \\
\text { The degree of effective use of each of production factors }\end{array}$ & $\begin{array}{l}\text { Organization for European Economic } \\
\text { Co-operation }\end{array}$ & Boel, 2003 \\
$\begin{array}{l}\text { Profit equals the result of productivity multiplied by Productivity Agency } \\
\text { adjusted price }\end{array}$ & $\begin{array}{l}\text { American Productivity Center } \\
\begin{array}{l}\text { The relationship between the output of production system } \\
\text { with the data used for production of output }\end{array}\end{array}$ & International Labor Organization \\
$\begin{array}{l}\text { A culture is a rational approach toward work and life, } \\
\text { aiming at making the activities purposeful in order to } \\
\text { realize better and more active life }\end{array}$ & $\begin{array}{l}\text { National Iranian Productivity } \\
\text { Organization }\end{array}$ & www.ilo.org \\
\hline
\end{tabular}

Mohanty (1998) compares traditional and modern viewpoints and states: "traditional views tend more to focus on final results, i.e. profit, although modern viewpoints focus on quality, and attribute the main cause of development of organizations and employees to improvement of processes and inputs".

\subsection{Productivity in manufacturing units}

Productivity in manufacturing units is defined as follows: quality and quantity enhancement of product to the ratio of spent cost. Each of manufacturing activities is a process in enhancing value. In all cases, productivity depends, in a great extent, on technology and management. The main target of manufacturing activities is to increase value added. Once these duties are discharged, the companies produce their product and present it to the customers (Sumanth, 1995).

\subsection{Effective factors of productivity in manufacturing units}

To promote productivity, first of all the influential factors of productivity must be recognized, precisely.

Two types of internal and external factors are considered (Prokopenko \& North, 1996). Internal factors are under control and capacity of individuals and managers inside the organization, who may be recruited by proper management and contemplation. These factors could be classified as input, output and process factors. Input factors include investment, factory, equipment, materials, energy, technology, technical knowledge and product design. Process factors consist of individuals, motivation, education, job, industrial relations, factory and equipment development, maintenance and repair, work and feedback methods, measurement, analysis of systems and method of organization management. Output factors include volume, production quantity, market share and penetrating into it, guarantee systems and warranty, product price, quality, product design innovations, packaging, after-sales services, timely deliver, availability of product and return of capital. External factors influence the organization from outside and are not under the capacity of individuals and managers inside the organization. Table 2 shows the research carried out for identification of the factors affecting productivity. 
Table 2

Factors affecting Productivity

Factors affecting Productivity

Employees, management, customer, marketing, working conditions, technology,

external factors, the way of establishment of equipment and personnel, skill of labor

force, quality of materials

General factors, organizational and technical factors, human factors

Production, technical changes and investment accumulation, human factor, innovation

and creativity, improvement and correction of methods of performing duties, management style, training, labor culture, Technological changes, labor force capability, the amount of capital proportionate to the labor force unit

Physical factors, mental factors

Labor technique, labor management, labor force and labor characteristics

Occupational performance of employees (physical conditions, social conditions,

capability, development of technology, personal conditions of individuals, official Sutermeister,1969

and non-official groups, capability)

\section{Customers relationship management}

Customers relationship management (CRM) is a term used to define how to interact with customer and management of the activities to establish durable and effective relationship with customer. The logic of CRM is "to control" and "to manage the entire process of rendering service to the customer. This means that before knowing the customer until the process of providing the service or product is over, it is necessary to know how to act to attract the customer to refer to the organization again. It is very important to consider CRM as a system; a system which specifies how to work with customers, how to solve their problems, how to encourage them to purchase the products and services of the company and how to have financial interactions with them (Brynjolfsson \& Hitt, 1998). CRM is applied to all processes and technologies that the organization uses to identify, choose, encourage, promote, maintain and serve the customer (Lawson-Body \& Limayem, 2004).

\subsection{The role of CRM on productivity}

Productivity has a close relationship with making the value of relation. The very important point is that it is likely that the value of manufactured product increases, but the manufactured products might not satisfy the needs, demands and expectations of customers. In this case, even establishing value added will not guarantee sustainable productivity, which may not be sustainable and fall after a short period. That is why Bryniolfsson and Hitt believe that the correct definition of productivity is the value made for the customer (Brynjolfsson \& Hitt, 1998). In case paying sufficient attention to the values, expectations, demands and needs of customers and the community is not one of the most radical targets and strategies of the organization, its sustainability in future is at risk even if productivity is in a favorable level for the time being. Stainer concentrated on this point that since the needs and demands of customers and the social environment is changing permanently, the areas of attention of organization to improve sustainable productivity should not be unchanged (Stainer, 1997). Oracle as one of pioneer in the field of CRM specifies 10 key factors for successful implementation of CRM. In 1996, Huff states his opinion about the customer satisfaction and productivity: there are outstanding and opposing opinions arising from the nature of relationship between customer satisfaction and productivity (Hammer \& Champy, 1993). This relationship is usually assessed positive in research into operations and management of production. A company that achieves high levels of customer satisfaction needs to use fewer resources in order to control the incomes, omit and or reduce extra work, guarantee and management of customer complaints, which results in reduction of expenses and therefore improved productivity (Sumanth, 1995).

\subsubsection{Return on investment rate (ROI) in customer relation management}

In simple words, return on investment rate is gained by dividing income to the made investment. Concerning the investment, the cost of ownership of customer relation management, post-ownership 
costs such as software annual license costs, software maintenance and permanent training of employees, consulting fees, hardware, and initial training of employees must be considered. On the other side, in calculation of incomes, what makes the problem sophisticated is the numerous tangible and intangible advantages. Tangible advantages include reduction of costs and growth of income by improving productivity of sales unit, increasing cross selling and up selling, and increasing customer protection rate. Intangible advantages may include increasing customer satisfaction, improving the ability to foresee market and develop product in conformity with the needs of customer. Although numerical calculation of these advantages is difficult, we may measure them by appropriate scales.

For above reasons it seems that measuring the rate of return on investment must be made in a longterm course. We need a course of time for CRM programs make notable advantages for the organization but it is not feasible to determine the actual time of achieving these results Satoshi, 2006). The fact is that through the following three steps we may enhance our success in the return on investment made in the field of management of customer relationship (Francis, 2002),

1)Understanding the value that the customer expects,

2) Making the customer's expected value in a profitable way,

3) Repetition of above steps.

\subsection{EFQM and the Role of CRM on Productivity}

In this section, we try to use the European model of organizational excellence to show the influence of CRM on productivity in manufacturing organizations. In this way, we look at CRM from two aspects: first CRM as an approach and rehabilitation that influences organizational productivity and second the results that will be expected from CRM to increase productivity are shown.

\subsubsection{Customer Relationship Management as Enabler}

\section{Customer Leadership}

Customer leadership includes creativity and conducting a customer-oriented business process and putting the customer in the center and study and analysis of customer needs.

In CRM system, a manager plays the role of a leader. According to a model standard, such characteristics as interest in making progress, intelligence, innovation and creativity, personal partnership, being charismatic, efficient interaction with customers, boosting the culture of customer orientation helps the manager to design efficient communication systems with customers, study and analyze the results of assessments and customer feedbacks, and permanently assess and supervise the products delivered to customer. One of the other duties of customer leaders is the issue of culture. It goes without doubt that the organization's culture is a central factor in determining readiness of that organization to implement customer orientation projects (Stainer, 1997). Implementation of technologies such as management of customer relationship needs changes in the organizational culture (Bradshaw \& Brash, 2001). The organization's culture should concentrate on the needs of customer because the manufacture is likely to provide a good product but the customers might be dissatisfied due to the type of delivery, weak services and or irresponsibility of the centers that contact the unsatisfied customer (Kim \& Kim, 2009).

\section{Customer strategy}

The organizational excellence European model holds that top organizations establish their strategy on the basis of the present and future needs and expectations of the beneficiaries particularly customers. Lindgreen et al. (2006) classified four customer orientation strategies as follows,

1) Customer strategy: this concentrates on how to attract new customers and also how to maintain and develop the relationships with the present customers. When the customer's strategy creates assurance and commitment, the organization's profitability will grow. 
2) Interaction with customer strategy: customer interaction depends on how an organization influences its customers and how the goods and services are delivered refer to these strategies. The said strategy encompasses all interactive processes, the contact points with employees and distribution channels. The aim here is to realize when and how the customers wish to interact with the organization.

3) The strategy to make value: making value is the main target of existence of this relationship and every strategy should concentrate on making value for the organization and its beneficiaries. The said strategy is seeking to answer this question that how the value is created and delivered to customer and how the periodical life value of customer could be anticipated based on the increased profitability.

4) Brand strategy: trade names are important determining factor in purchasing the goods and services of an organization more than once, which leads to higher levels of customer satisfaction.

\section{Labor Force Skill and Motivation}

Dealing with competency, capability and appreciating the characteristics of advanced organizations. In order for an organization to appropriately manage relationship with customer, it needs to consider the human issues related to employees (Shirani \& Safari, 2007). All personnel in the organization must understand their roles and satisfy the required capabilities and the tendencies defined in the staff recruitment programs (Georgiadis \& Lane, 2001). In order to maintain valuable employees, first these employees must be identified and be then rewarded based on customer-oriented behavior and performance. Since all parts of the organization cooperate with each other to satisfy the customer, it is necessary to consider a reward system to motivate in these areas (Clarck \& payne, 1995). The following points must be considered in the customer-oriented organizations by understanding the importance of these effective human elements:

1) All employees should be familiar with the philosophy of customer friendliness. They should collectively do their best to satisfy the needs of customer and supply the demands and satisfy the expectations of customer.

2) It is necessary to boost the joint goals between the management, employees and customers. Realization of this goal will benefit three groups depending on the cooperation of employees and management.

3) It is necessary to try to encourage the employees to cordial partnership instead of using imperative commands, and instead of blindly abiding by regulations, take authoritative decisions by employees.

4) Motivate the employees by rewarding them financially and non-financially to encourage them and make them focused to do their best in order to attract and maintain the customers.

\section{Using Information Technology Capacity}

Identifying and evaluating modern and replacing technologies is the main topic of organizational excellence European model with regard to the strategy. One of these modern technologies is to use the capacity of technology in the organizations. Substructure is a key need for CRM (Sin, 2005). The information technology facilitates changes in working operations and establishes innovative methods for relationship of company and customers and suppliers, and hence helps redesigning the business processes (Hammer \& Champy, 1993). In fact, the role of information technology tools in management of relations is to facilitate various processes of customer such as categorization of customers based on the value or foreseeing their behavior.

From technical point of view, information technology is a capability, which allows the organizations to grow a close relationship with customers, analyze the customer information and provide a logical 
view of the customer (Goodhue et al., 2002). Chang and $\mathrm{Ku}$ (2009) defined management of relationship with customer as a combination of marketing efforts, business processes and technology, which altogether allows the companies perceive their customers from different viewpoints. According to their point of view, CRM uses information technology and knowledge in order to integrate marketing, sales and services and makes changes to improve the customer satisfaction, promote loyal customers and finally increase the income of present customers. In Table 3, the benefits that information technology produces in customer relationship management are shown.

\section{Table 3}

IT Benefits on CRM

\begin{tabular}{ll}
\hline IT Benefits & Sources \\
\hline Improvement in Relationship and & Beck et al., 2005; Caillaud \& Passemard, 2001; Migiro, \& Ocholla, \\
Coordination with Customers & 2005
\end{tabular}

\section{Customer orientation process as part of organizational processes}

The Criterion number 5 of European organizational excellence model refers to this point that the processes are designed and managed for customers in an organized form and with regard to creativity for complete satisfaction and create added value. One of the main processes related to this criterion is the process of customer orientation. Customer orientation process is management of useful bilateral relations from seller's point of view (Richards \& Jones, 2008).

Innovations in designing and producing the product

According to the criterion number 5 and 6 of European model of organizational excellence, top organizations do not ignore creativity and are always seeking to find approaches in order to realize this goal. Thinkers believe that customer relationship management leaves positive influence on the creativity capabilities (Lin \& Chen \& Chiu, 2010).

\subsubsection{The outcomes of CRM}

\section{Increasing income and reducing cost}

According to the criterion number 9 of excellence model, one of the results of excellence model that is influenced by customer relations management, is increased income and reduced cost. CRM is the basis of financial achievements of organizations. Customer relations management will bring great competition advantages for the companies by producing higher income and lower operational expenses (Jackson,1994). Management of relationship with customer uses the following three main elements to increase the organization's income:

o Relationships: making effective and appropriate relationship between the internal and external parts of organization and the customer.

o Return and productivity: increasing the organization's working efficiency, using information 
technology.

o Decision making: gathering appropriate information will assist the system in presenting more appropriate reports for decision making by managers. Removing non-profitable customers could also lead in increasing profit and reducing costs in the organizations unless if there are political, legal and or social considerations to take into account in this regard.

\section{Increasing the market share}

Increased market share is one of the other results of criterion number 9 of European organizational excellence model where customer relations management has a role. Gaining favorable financial results is not always a sign of success in market. Many organizations believe that good customers are those who have a great share in profitability of organization; but today profitability and income producing are not the only aspects in defining the customers.

\section{Value added}

One of the other outcomes of European organizational excellence model resulting from customer relations management is the value added.

Lambert pointed out to the way of influence of CRM process on the financial performance of company. In another words, it specifies how management of customer relations influences sales, cost price of sold goods, total costs, investment on inventory, other current assets and investment in fixed assets (Lambert, 2010).

\subsubsection{A Suggestive model of CRM effects on productivity}

As explained in the previous sections, the role of customer relations management on productivity was studied from the following two respects:

\section{- Enabling criteria}

Criterion number 1- customer leadership and the culture of customer orientation

Criterion number 2- customer relations strategy

Criterion number 3- Skill and motivation of labor force

Criterion number 4- Customer relations technology (information technology)

Criterion number 5-Customer relations process and innovation

- Results:

Criterion number 6- Customer satisfaction and loyalty

Criterion number 7- Employees satisfaction

Criterion number 9- Increased income, added value market share and reduced cost.

The Enabler criteria and the results of customer relations management are not apart from each other and influence each other. Fig. 1 shows different components involved with the proposed model.
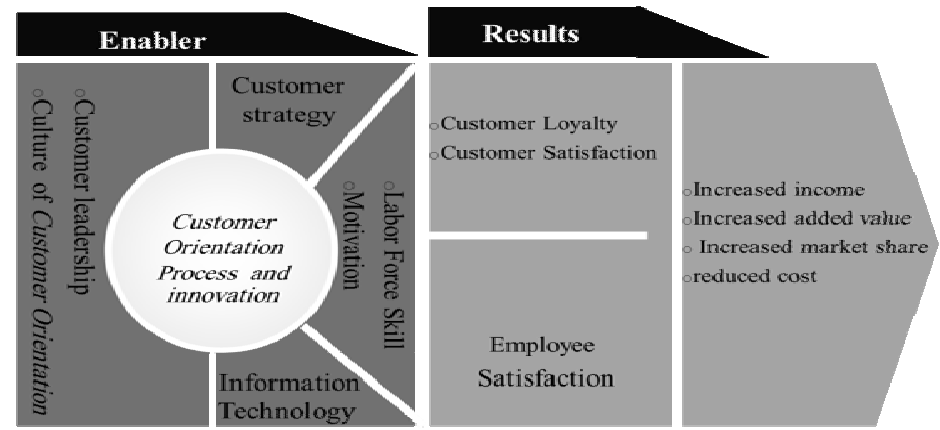

Fig. 1. A Suggestive model for the role of CRM on Productivity 


\subsubsection{Balanced credit card and the influential indicators of customer orientation on productivity}

According to Table 4, using success indicators in four aspects of balanced credit card, the role of CRM in productivity of organization has been shown.

\section{Table 4}

Affecting factors of customer orientation on productivity

\begin{tabular}{|c|c|c|c|c|}
\hline Aspect & Success factors & Affecting indicators & Factors type & sources \\
\hline Financial & $\begin{array}{l}\text { Profitability } \\
\text { capability }\end{array}$ & $\begin{array}{l}\text {-Net sales } \\
\text {-ROI }\end{array}$ & Output & $\begin{array}{l}\text { Sirikrai \& Tang, 2006; Kim \& Kim, } \\
\text { 2009) }\end{array}$ \\
\hline \multirow{3}{*}{ Customer } & Customer value & $\begin{array}{l}\text {-Receiving quality } \\
\text {-Receiving price }\end{array}$ & Output & $\begin{array}{l}\text { Sirikrai, \& Tang, 2006; Zineldin, 2005; } \\
\text { Zhou et al., 2009; Setijon \& Dahlgaard, } \\
\text { 2007; Oh, } 1999\end{array}$ \\
\hline & $\begin{array}{l}\text { Customer } \\
\text { satisfaction }\end{array}$ & $\begin{array}{l}\text {-Products or services } \\
\text { quality } \\
\text {-accessing to product or } \\
\text { services }\end{array}$ & Output & $\begin{array}{l}\text { Kim \& Kim, 2009; Gilbert, 2000; } \\
\text { Adebanjo, 2001; Rahman, } 2004\end{array}$ \\
\hline & Customer loyalty & $\begin{array}{l}\text {-Products or services } \\
\text { quality }\end{array}$ & Output & $\begin{array}{l}\text { Kim et al., 2004; Bowen \& Chen } \\
\text {,2001; Augusto de Matos , } 2009\end{array}$ \\
\hline \multirow[t]{2}{*}{ Process } & $\begin{array}{l}\text { Customer } \\
\text { attraction }\end{array}$ & $\begin{array}{l}\text {-product s price } \\
\text {-product packaging } \\
\text {-after sales services }\end{array}$ & Output & $\begin{array}{l}\text { Ahmed et al., 2005; Farquhar \& } \\
\text { Panther, } 2008\end{array}$ \\
\hline & $\begin{array}{l}\text { Customer } \\
\text { Maintaining }\end{array}$ & $\begin{array}{l}\text {-customers interest in sales } \\
\text { people }\end{array}$ & process & Ahmed et al., 2005 \\
\hline \multirow{5}{*}{ Infrastructure } & IT & $\begin{array}{l}\text {-CRM Technology } \\
\text {-Integration of customers } \\
\text { Information }\end{array}$ & process & Curry \& Kkolou, 2004 \\
\hline & Culture & $\begin{array}{l}\text {-Culture of customer } \\
\text { orientation } \\
\text {-Culture of continuous } \\
\text { improvement }\end{array}$ & Process & $\begin{array}{l}\text { Curry \& Kkolou, 2004; Ahmed et al., } \\
2005\end{array}$ \\
\hline & Employees & $\begin{array}{l}\text {-Training } \\
\text {-Relations with Employees } \\
\text {-Employees commitment } \\
\text { in customer orientation } \\
\text { Acting by Employees like } \\
\text { partners }\end{array}$ & process & $\begin{array}{l}\text { Ahmed et al., 2005; Curry \& Kolou, } \\
2004\end{array}$ \\
\hline & $\begin{array}{l}\text { Organization's } \\
\text { alignment }\end{array}$ & $\begin{array}{l}\text {-Customer orientation as } \\
\text { the mission of organization } \\
\text {-Adaption of the strategies } \\
\text { with the mission of the } \\
\text { organization } \\
\text {-Adaption of processes } \\
\text { with customers needs and } \\
\text { wants } \\
\text {-continuous assessment of } \\
\text { processes effectiveness }\end{array}$ & & $\begin{array}{l}\text { Ahmed et al., 2005; Curry \& kolou, } \\
\text { 2004; Dreyer, \& Grønhaug, } 2004\end{array}$ \\
\hline & Partnership & $\begin{array}{l}\text {-effective relations with } \\
\text { partners like sales people } \\
\text {-diversity of sales people }\end{array}$ & Process & Ahmed et al., 2005 \\
\hline
\end{tabular}

\section{Case Study}

This research is a case study using questionnaire method. In this study the extent of the influence of the factors that influence productivity in manufacturing organizations and the role of CRM in it are specified. The respondents of questionnaire are two expert groups of household appliances manufacturing industries and the experts of Philver manufacturing company. All frequency tables are related to the questions in the questionnaire and the frequency of tested hypotheses is available in the annex. In order to identify the most important factors of productivity and determine the influence of 
customer orientation on it in household appliances manufacturing companies, experts questionnaire was prepared. To prepare this questionnaire, the research carried out in the chapter of review of the sources of all productivity effective factors was gathered and the factors with no influence on the productivity of manufacturing organization according to experts were removed. In this way, 55 factors were identified as the productivity effective factors in manufacturing companies, which according to Table 5 were classified in 6 main groups. The way of responding to the questionnaires is using Likert spectrum. In the stage of prioritization of productivity effective factors, the factor with higher mean and lower standard deviation will have a higher priority.

$$
\mathrm{CV}=\frac{\alpha}{\mu} \quad \mathrm{CV}: \text { Coefficient of Variation , } \mu: \text { Mean, } \alpha: \text { Standard Deviation (1) }
$$

Table 5

Factors affecting productivity

\begin{tabular}{lll}
\hline Factors affecting productivity & Questions & Degree of importance \\
\hline Customer orientation & $1-12$ & 88.6 \\
Production methods & $13-20$ & 77 \\
Production factors & $21-31$ & 71 \\
Managing and organizing & $32-44$ & 77 \\
Factors of motivation & $45-50$ & 67 \\
Degree of market and product competitiveness & $51-55$ & 79.8 \\
\hline
\end{tabular}

Table 6 shows 20 top factors that influence productivity in household appliances manufacturing industries in Iran, based on the opinion of experts.

\section{Table 6}

Factors affecting productivity

\begin{tabular}{lcccc}
\hline Factors Affecting productivity & AVE. & Deviation & Factor of changes & PRIORITY \\
\hline Customer orientation as mission of organization & 4.93 & 0.26 & 0.52 & 1 \\
\hline Customer loyalty & 4.87 & 0.35 & 0.072 & 2 \\
Quality of products & 4.13 & 0.35 & 0.085 & 3 \\
\hline Customer satisfaction & 4.80 & 0.41 & 0.086 & 4 \\
\hline Skill of work labor & 4.80 & 0.41 & 0.086 & 5 \\
\hline Amount of new technology usage in contrast & 4.20 & 0.41 & 0.099 & 6 \\
competitors & 4.67 & 0.49 & 0.105 & 7 \\
\hline Culture of customer orientation in organization & 4.27 & 0.46 & 0.107 & 8 \\
Overview of processes and designing of new processes & 4.53 & 0.52 & 0.114 & 9 \\
\hline Effective managing of customers & 4.53 & 0.52 & 0.114 & 10 \\
\hline Employees being responsible & 4.53 & 0.52 & 0.114 & 11 \\
\hline Manager capability & 4.40 & 0.51 & 0.115 & 12 \\
\hline Existence of partnership atmosphere & 4.40 & 0.51 & 0.115 & 13 \\
\hline To be Strategic oriented & 4.47 & 0.52 & 0.116 & 14 \\
Changing viewpoint from product orientation to & 4.47 & 0.52 & 0.116 & 15 \\
customer orientation & 4.47 & 0.52 & 0.116 & 16 \\
\hline Appropriate relations with customers & 3.73 & 0.46 & 0.123 & 17 \\
\hline Brand of organization & 3.73 & 0.46 & 0.123 & 18 \\
\hline Introducing new methods of production & 3.20 & 0.41 & 0.129 & 19 \\
\hline Establishing of management information systems & 3.67 & 0.49 & 0.133 & 20 \\
\hline Appropriate Pm planning & & & \\
\hline Culture of Continuous improvement in organization & & \\
\hline
\end{tabular}

\subsection{Prioritization of customer orientation factors on productivity in Philver company}

As Philver Mfg. Company is in the present competitive market of Iran, therefore it seems necessary to have a system by which the function of customer relations process in relation with company's productivity could be assessed and to increase productivity, identify the weaknesses and advantages 
of customer relations management process and present appropriate strategies to improve it. Fig. 2 favorably shows the difference of present status of company in each of Criterions of European organizational excellence model and comparison with favorable status

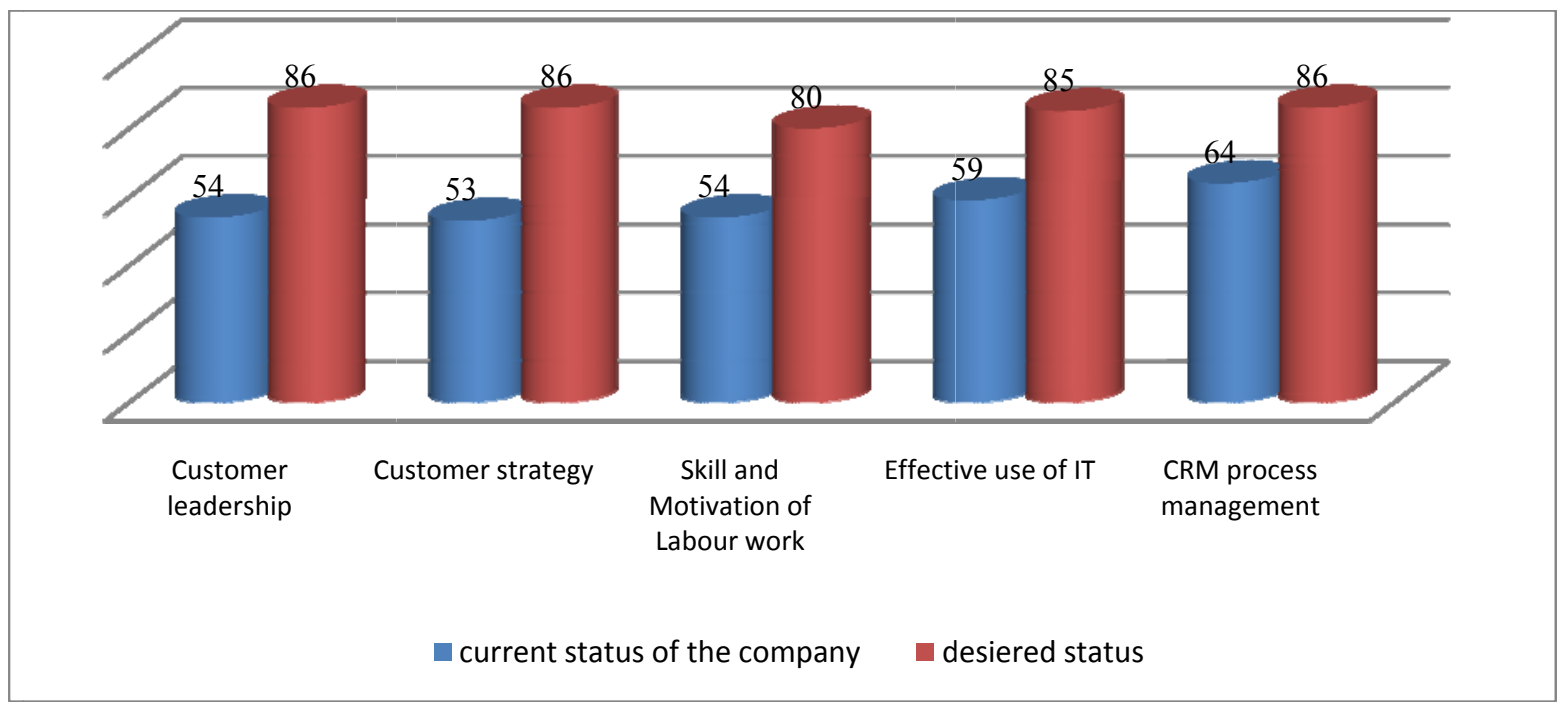

Fig. 2. Comparison between current state and ideal state of customer orientation

According to Fig. 1, the process of customer relations of Philver company does not have an appropriate status compared to favorable status. Based on the potencies of the company it is recommended to develop improvement plans to eliminate the weak points.

\section{Conclusion}

This research was an attempt to study the most important factors of productivity of the organizations, which are active in manufacturing of household appliances. For this reason first after studying different productivity effective factors, the most important factors of productivity were compiled in a questionnaire by help of experts of this industry, and the factors according to the native culture of Iran. Then through an opinion poll from the actives of this industry, each of these factors were weighed and the priority of each factor was gained by use of changes coefficient formula. Using European organizational excellence model and the quantity data obtained (experts opinions mean), the process of customer orientation of Philver manufacturing company was assessed. The obtained results proved major weakness of customer orientation process of the organization in each of the criteria of excellence model. The results of this survey provided a figure to measure the status of customer leadership, strategy, skill and motivation of labor work, effective use of information technology and process management in CRM implementation of this case study.

\section{References}

Abouzeedan, A., \& Busler, M. (2006). Information technology and small and medium-sized enterprises management: The concept of 'firm impact sphere'. Global Business Review, 7, 243-257.

Adebanjo, D. (2001).Understanding customer satisfaction- a UK food industry case study, British Food Journal, 103(1), 36-45.

Augusto de Matos, C., Luiz Henrique, J. \& de Rosa, F.(2009). The different roles of switching costs on the satisfaction-loyalty relationship, International Journal of Bank Marketing, 27(7), 506-523.

Ahmed, A. \& Ahmed, N., \& Salman, A.(2005). Critical issues in packaged food business, British Food Journal, 107(10), 760-780. 
Beck, R., Wigand, R.T., \& König, W. (2005). The diffusion and efficient use of electronic commerce among small and medium-sized enterprises: an international three-industry survey, Electronic Markets, 15(1), 38-52.

Brynjolfsson, E., \& Hitt, L.M. (1998). Beyond the productivity paradox. Communications of the ACM, 41(8), 49-55.

Boel, B. (2003).The European Productivity Agency and transatlantic relations. Museum Tusculanum Press.

Bowen, J.T \& Chen Sh. (2001). The relationship between customer loyalty and customer satisfaction, International Journal of Contemporary Hospitality Management, 13(5), 213-217.

Bradshaw, D. \& Brash, C.(2001). Managing customer relationships in the e-business world: how to personalise computer relationships for increased profitability, International Journal of Retail and Distribution Management, 29(11-12), 520.

Cetin, B., Akpinar, A. \& Ozsayin, D. (2004). The use of information and communication technologies as a critical success factors for marketing in Turkish agri-food companies. Food Reviews International, 20, 221-228.

Curry, A. \& Kkolou, E. (2004), Evaluating CRM to contribute to TQM improvement - a cross-case comparison. The TQM Magazine, 16(5), 314-324.

Chang, H. H., \& Ku, P.W. (2009). Implementation of relationship quality for CRM performance: Acquisition of BPR and organisational learning. Total Quality Management \& Business Excellence, 20(3), 327-348.

Caillaud, E., \& Passemard, C. (2001). CIM and virtual enterprises: A case study in SME. International Journal of Computer Integrated Manufacturing, 14(2), 168-174

Dreyer, B. \& Grønhaug, K.(2004). Uncertainty, flexibility, and sustained competitive advantage, Journal of Business Research, 57, 484-494.

Farquhar, J.D., \& Panther, T. (2008). Acquiring and retaining customers in UK banks: An exploratory study, Journal of Retailing and Consumer Services, 15, 9-21.

Francis, B. (2002). Is it worth it? ROI on CRM , presented at the academy of marketing conference , Sydney, Australia.

Gilbert, R.G.(2000). Measuring internal customer satisfaction, Managing Service Quality, Volume 10(3), 178-186.

Georgiadis, M., \& Lane , K .(2001). Customer marketing organization, Mckinesey and Co, New York.

Goodhue, D.L., Wixom , B. H. \& Watson, H. J. (2002). Realizing business benefits through CRM: hitting the right target in the right way. MIS Quarterly Executive, 1, 79-94.

Hammer, M, \& Champy, J. (1993). Reengineering the corporation. Harper business, New York.

Homyun J., \& Kyonghoon K., \& Juhyung K., \& Jaejun K.(2009). Labour productivity model for reinforced concrete construction projects. Construction Innovation: Information, Process, Management, 11(1), 92-113.

Kim, M. \& Park, M. \& Jeong, D. (2004) the effects of customer satisfaction and switching barrier on customer loyalty in Korean mobile telecommunication services, Telecommunications Policy, 28, 145-159.

Kim, H.-S., \& Kim Y.G. (2009).A CRM performance measurement framework: Its development process and application. Industrial Marketing Management, 38, 477-489.

Matzer, M. J. (1998). Productivity Improvement Techniques, Washington, DC, Internationa City Management Association.

Mohanty, R.P. (1998). Understanding the integrated linkage: quality and productivity, Total Quality Management, 9(8), 753-765.

National of Iranian Productivity Organization.(1992), Productivity Movement, Tehran, Iran.

Jackson, D. (1994). Relationship Selling: the personalization of relationship marketing Asia. Australia Marketing Journal, 2(1), 45-54. 
Migiro, S. O., \& Ocholla, D.N. (2005). Information and communication technologies in small and medium scale tourism enterprises in Durban, South Africa. Information Development, 21, 283294.

Lambert, D. M. (2010). Customer relationship management as a business process. Journal of Business \& Industrial Marketing, 25(1), 4-17.

Locke, S. (2004). ICT adoption and SME growth in New Zealand. Journal of American Academy of Business, 4, 93-102.

Lin, B. W. (2007). Information technology capability and value creation: Evidence from the US banking industry. Technology in Society, 29, 93-106.

Lin, R.J., Chen, R.H., \& Chiu, K.K.S. (2010). Customer relationship management and innovation capability: an empirical study. Industrial Management \& Data Systems, 110(1), 111-133.

Lybaert, N. (1998). The association between information gathering and success in industrial SMEs: The case of Belgium, Entrepreneurship \& Regional Development, 10, 335-351.

Lawson-Body, A. \& Limayem, M. (2004). The impact of customer relationship management on customer loyalty: The moderating role of web site characteristics. Journal of Computer-Mediated Communication, 9(4), 28-38.

Lindgreen, A., Palmer, R., Vanhamme, J., \& Wouters, J. (2006). A relationship-management assessment tool: Questioning, identifying, and prioritizing critical aspects of customer relationships. Industrial Marketing Management,35, 57-71.

Oh, H. (1999). Service quality, customer satisfaction, and customer value: A holistic perspective. International Journal of Hospitality Management, 18(1), 67-82.

Prokopenko, J. (1993).Productivity Management, A Practical Handbook.

Prokopenko, J., \& North , K. (1996). Productivity and Quality Management: A modular Programme, edited by, ILO.and APO.

Rahman, Z. (2004). Developing customer oriented service: a case study, Managing Service Quality, 14(5), 426-435.

Richards, K \& Jones, E. (2008). Customer relationship management: Finding value drivers. Industrial Marketing Management ,37, 120-130.

Sirikrai, S. B., \& Tang, J. C. S. (2006). Industrial competitiveness analysis: Using the analytic hierarchy process. Journal of High Technology management Research, 17, 71-83.

Setijon, D., \& Dahlgaard, J.J. (2007). Customer value as a key performance indicator (KPI) and a key improvement indicator (KII). Measuring Business Excellence, 11(2), 44-61.

Stainer, A. (1997). Capital input and total productivity management. Management Decision, 35(3), 224-232.

Satoshi ,U. (2006). The impact of Customer Relationship Management, Japan.

Sumanth, D. J. (1995). Productivity Engineering and Management, McGraw-Hill, Inc Tata Mc GrowHill Edition.

Sin, L.Y.M., Tse A.C.B., \& Yim F.H.K.(2005). CRM: Conceptualization and scale development. European journal of marketing, 39(11/12), 1264-1290.

Sutermeister, R.A. (1969). People and productivity. New York, McGraw Hill.

Tan, Z. A. \& Ouyang, W. (2004).Diffusion and impact of the Internet and e-commerce in China. Electronic Markets, 14, 25-35.

Tangen, S. (2002b).Understanding the concept of productivity. Proceeding of the 7th Asian-Pacific Industrial Engineering and Management systems Conference, Taipei.

Zineldin, M. (2005). Quality and customer relationship management (CRM) as competitive strategy in the Swedish banking industry. The TQM Magazine, 17(4), 329-344.

Zhou, K.Z., Brown, J.R., \& Dev, C.S. (2009). Market orientation, competitive advantage, and performance: A demand-based perspective, Journal of Business Research, 62, 1063-1070. 